\title{
Assessment of Traffic Delay Problems and Characteristics at Urban Road Intersections: A Case Study of Ilorin, Nigeria.
}

\author{
Tolu Isaac Atomode \\ Department of Geography, Faculty of Arts and Social Sciences, Federal University Lokoja, P.M.B 1154, \\ Lokoja, Kogi State, Nigeria
}

\begin{abstract}
Traffic delay problems are manifesting in many of the major urban centres in Nigeria. The paper examined traffic delay problem and its causes at selected road intersections in Ilorin, Nigeria. The characteristics of the intersections that predispose them to delay problem and the spatial pattern of traffic delay at the road intersections were also identified. In addition, traffic volume and delay characteristics were estimated. Data were collected through direct field surveys on intersection characteristics, traffic volume, composition, delay causes and land use activities. The analysis of data collected revealed that variations exist in traffic flows and delays at the studied intersections. Also, traffic delays are discovered to be associated with the traffic volumes at the various junctions which ultimately translate to traffic congestion. Furthermore, traffic wardens and parking problems were found to be the greatest causes of delays at the road intersections in the city. The study therefore recommends that the road intersections be signalized and vehicle parking be strictly prohibited to reduce traffic congestion and delays at road intersections in the city.
\end{abstract}

Keywords: Land Use, Road Intersections, Traffic Congestion, Traffic Delay, Traffic Volume.

Submitted Date 11 June 2013

Accepted Date: 17 June 2013

\section{Introduction}

Traffic delay problems are manifesting in many of the major urban centres in Nigeria. They are indeed becoming a menace to free flow of traffic in these cities. These problems are caused by ineffective use of road space and growth in the number of vehicles on our roads. The urban road network plays a key role in the urban spatial structure. It is the main city social-economy activities and transportation carrier [1]. In other words, road network constitutes an important element in urban development as roads provide accessibility required by different land uses. The proper functioning of urban areas therefore depends on efficient transport network, which is a backbone to their very existence [2]. Road intersections (where traffic flows in different directions converge) play an important role in the road network. They are the most complex locations in a traffic system and they have a very considerable influence on vehicle safety and movement's efficiency.

A major characteristic of the urban road network is that it contains many intersections. As a result, the traffic situation in urban areas is characterized by many small disturbances, in comparison to highways that in general show fewer disturbances. Consequently, traffic delay is often a prominent feature of urban road intersection. The most noticeable feature of traffic congestion (a problem which has characterized almost all urban areas in the world, especially in the developing countries) is traffic delay. Traffic delay can be defined as the time lost due to traffic friction and traffic devices [3], or more simply as unwanted journey time [4]. In other words, traffic delay is the inability to reach a destination in or at, a satisfactory time due to slow or unpredictable travel speeds.

Urban road intersections easily become the worst hit of traffic delay. This is because, at intersections, vehicular flows from several different approach (link/edge) making either left-turn, through and right-turn movements seek to occupy the same physical space at the same time [5]. In addition to these vehicular flows, pedestrians also seek to use this space to cross the streets and thereby worsening the already bad traffic situation. Thus, the most critical points, from capacity, congestion and safety viewpoints for the operation of an urban road network are the intersections [6].

While considering the contribution of freight vehicles to traffic delays in Lagos, Ogunsanya noted that, $54.7 \%$ of the delays experienced in Lagos were at road intersections [7]. In a similar work on the causes of delay in Ilorin, Ogunsanya observed that, of the various types of delay, those that are caused by road intersections are the greatest accounting for $31.75 \%$ [8]. However, the characteristics and causes of traffic delays at road intersections were not examined. It is on this note that this study investigates the spatial pattern of traffic delay at road intersections in Ilorin as well as identifies the factors that predispose them to the problem. 
The issue of traffic delay (especially at road intersections) in Ilorin like many other state capitals in Nigeria draws significant attention each day. Intra-urban movements to work, recreational centres, markets, shops and schools are becoming more and more difficult and are characterized by discomfort, delays, waste of time, energy and resources. The problem is more pronounced during the peak periods of morning and evening when vehicles stand still in long queues resulting in stress and reduction in the productive hours of commuters. Although the situation in Ilorin has not grown out of control, signs of potential bottlenecks are already emerging along some routes.

\section{Conceptual Framework}

Traffic delay can be fixed or operational. Fixed delays occur mainly at road intersection where a vehicle may stop, to allow those along the intersecting roads pass. In this type of delay, a single vehicle on a traffic lane may be held up for few seconds or minutes in obedience to the traffic light even when no vehicles are passing from the intersecting roads. Such delays are caused by traffic signals, stop signs, and yield signs, among others. The operational delay on the other hand are influenced by other vehicles' ineffectiveness as in the case of breakdowns, accidents, parking and maneuvering problems [7]. They can also result from pedestrian crossings, high volume of flow, lack of capacity merging and weaving traffic [3] [9].

According to O'flaherty [9], the delay which an individual vehicle experiences at a roundabout (a type of intersection) can be regarded as consisting of two components. The first of these might be called 'moving delay', since it is caused by the vehicle having to slow down, travel extra distance about a roundabout and then accelerate to the normal speed of the road. The second component of the vehicle delay is the 'obvious delay', caused by the vehicle having to queue in order to get into the roundabout and by obstruction from other vehicles while in the roundabout. Smith [10] noted that, often in urban road networks the delay to traffic on one approach to a junction/intersection depends on the flow along other approaches, especially when the intersection is not signalized.

Generally, delay at road intersection can be of different types. The most commonly used forms as noted by Mchsane et al [5] are defined as follows;

- Stopped time delay: This is the time a vehicle is stooped while waiting to pass through the intersection. It includes only the time the vehicle is actually stopped waiting at the red signal. It starts when the vehicles reaches a full stop, and ends when the vehicle begins to accelerate.

- Approach delay: Includes stopped time, but also includes the time lost when a vehicle decelerates from its ambient speed to a stop, as well as while accelerating from the back to its ambient speed. It is measured as the time scale differential between the actual paths extended as if the light had been green on arrival.

- Travel time delay: This is defined as the difference between the drivers' desired total time to traverse the intersection and the actual time required to traverse it. It is measured as the time scale difference between the drivers' desired time at any given distance from the origin, and the actual time. This value varies according to the distance at which it is measured. For a signalized intersection, it is measured at the stop line, as the vehicle enters the intersection.

- Time in-queue delay: This is the total time from a vehicle joining an intersection queue to its discharge across the stop-line or the curb-line.

- Aggregate delay: This is stated in terms of the total vehicle-hours (vehicle-seconds, or vehicle-minutes) of delay experienced by all vehicles traversing the intersection during some specific time period.

- Average per vehicle delay: This is stated in terms of sec/veh (or hr/veh, or min/veh) of delay, also for some specific period.

In transportation systems, queues/delays are formed whenever the number of arrivals at a given location exceeds the maximum rate at which vehicles can go through the location. When such a situation occurs, the excess vehicles are stored upstream of the bottleneck or service area and their departure is delayed to a later time period. Depending on the type of service provided, the queues that are formed may be either moving or completely stopped. Typically, moving queues are formed at locations where the flow of vehicles across the bottleneck or service area is never completely stopped. Stopped queues occur on the other hand when there are completely interruptions of service for a significant amount of time.

\section{Study Area}

Ilorin is medium-sized city which is situated in the traditional zone between the forest and savannah regions of Nigeria and serves as a gateway city between the northern and the southwestern part of Nigeria [8] and [11]. The city lies between Longitudes $4^{0} 2^{\prime} 20$ and $4^{0} 35^{\prime} 45$ : and between Latitudes $8^{0} 25^{\prime} 00$ and $8^{0} 31^{\prime} 30$ North [12]. Ilorin like many other state capitals is an important industrial, commercial, social and health, educational and administrative centre.

The creation of Kwara state and the choice of Ilorin as the state capital have resulted in its rapid population increase and area expansion [13]. In recent years, due to improved economic condition of the people, 
there has been an increase in the level of car ownership which consequently led to increase demand for transport facilities. However, in the absence of planned provision for transport infrastructures and services, the available road facilities are over-stretched beyond the volume they can reasonably cope with [8]. In addition, poor land use planning and poor traffic control measures have made traffic delay and congestion an important problem on the major roads and their intersections in Ilorin.

\section{Materials And Methods}

The data required for this study include information on intersection characteristics and road network; traffic volumes and characteristics; traffic delay and causes; and land use activities. The road network map of Ilorin with grid reference at one degree interval was used for identification of the studied intersections. As it is not possible to study all the intersections in the city, a sampling technique was employed and a ten per cent sample of the intersections in each four combined grid squares at 2 degrees intervals was selected at random. Some major intersections which were hitherto ignored by sampling were also included. Through this process, the following intersections were selected: (1) Saw-mill/Air Port; (2) Surulere/Agbo-oba; (3) Oloje/Mt. Carmel College; (4) Taiwo/Ita-Amodu; (5) Murtala/Amilegbe; (6) Tanke/Tipper Garage; (7) Gaa-Akanbi/Offa Garage (see Fig. 1).

A reconnaissance survey of the study area was first carried out at the selected intersections to identify the characteristics that predispose them to recurrent traffic delay. In addition, observatory survey was carried out at each of the selected intersections to estimate traffic delay. The traffic delay data could either be collected by observers located at strategic positions along the intersections (stationary observation) or by vehicle-borne observers (moving observation). Since the studied intersections can be observed within the view of the observers, the former method was adopted for this study. It involves the filling of a prepared form (by trained field assistants) showing the time of delay, length of delay (with the aid of a stop watch), causes of delay, and the type of vehicle involved. The observation was carried out as vehicles enter the intersections, since this is when delays are experienced. For the purpose of easy data collection, stopped delay was used. It is the most easily observed delay and was limited to a total halt in vehicles' movement [5] [7]. The observation was carried out in all the approaches to the intersections.

This was followed by traffic census conducted manually using simple hand-tally method to estimate the volume and composition of traffic at the intersections. A continuous count of all vehicles by class/category that passed through the intersections was done by field assistants. The field assistants were instructed to concentrate on a single lane each, and count the vehicles as they depart the intersections. This is because turning movements cannot be fully resolved until vehicles depart the intersections. The number of field assistants at any intersection was determined by the number of legs or approaches to the intersection.

The study was limited to peak periods because the peak hour traffic study is particularly useful in that it provides most important information concerning maximum traffic loads imposed upon the road network and as such relates to the capacity analysis and the design of future facilities [14] and [8]. Therefore, the peak hour periods of morning and evening peaks of 7.00a.m to $9.00 \mathrm{a} . \mathrm{m}$ and $3.00 \mathrm{p} . \mathrm{m}$ to $6.00 \mathrm{p} . \mathrm{m}$ respectively were used. The data were collected for three consecutive days (i.e. Monday, Tuesday, and Wednesday) of which the average was then used.

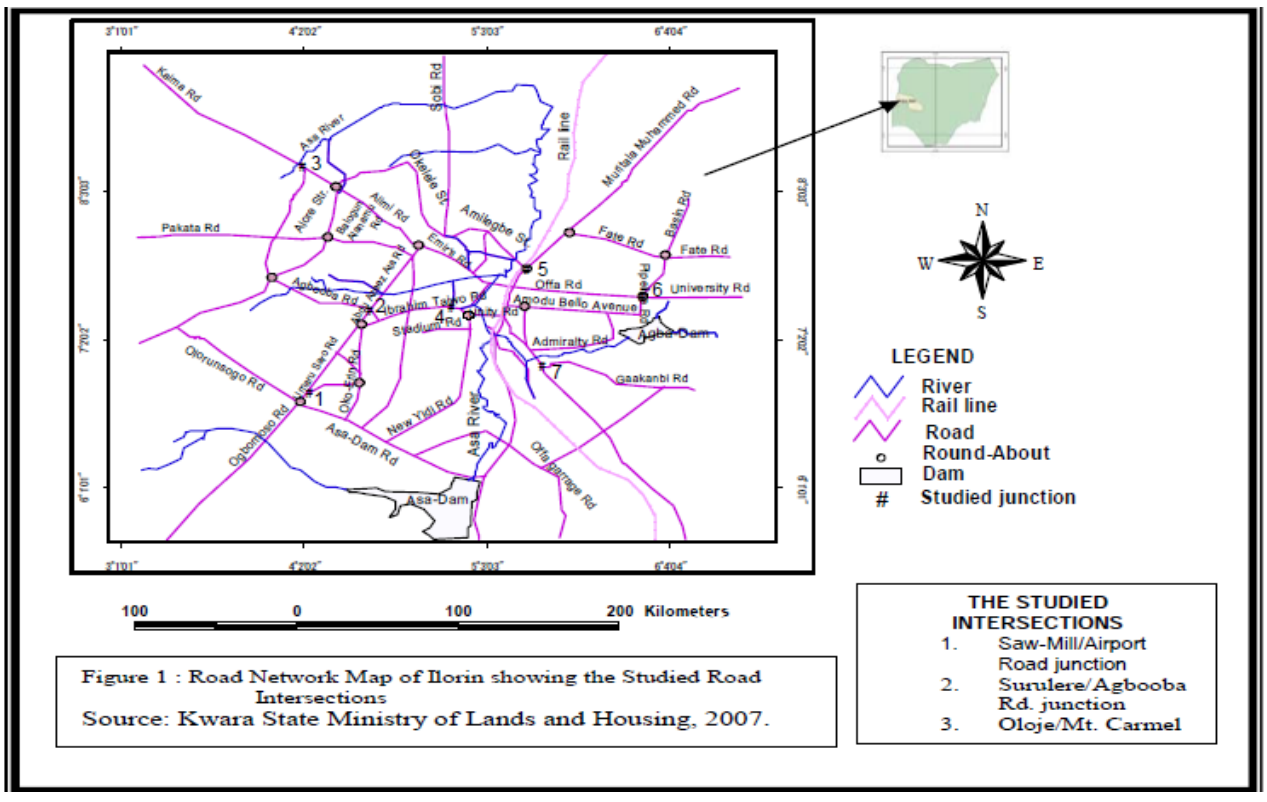




\subsection{Characteristics of the Selected Intersections}

\section{Discussion And Results}

The sampled intersections are comprised of 4-legged and 3-legged road junctions selected from different locations on major roads in Ilorin. The intersections serve as links to major routes which connect different types of land use activities in the study area. All the studied intersections are non-signalized but traffic flows are controlled by traffic wardens. Also common to all the intersections are the presence of road-side hawkers and traders, and the location of retailing shops along the intersecting roads. These result in road-side obstructions and parking problems from customers who patronize the sold products and thereby impeding the free movements of vehicles. Associated with these problems are the problems of narrowness and poor or no channelization of the intersecting roads to separate the traffic streams. TABLE 1 shows the characteristics of the studied intersections.

Table 1: Intersection Characteristics and Associated Land-use

\begin{tabular}{|l|l|l|l|}
\hline S/N & Intersection Name & $\begin{array}{l}\text { Intersection } \\
\text { Types }\end{array}$ & Land-use Characteristics \\
\hline 1 & Sawmill/Airport & 3-legged & $\begin{array}{l}\text { Institutional, Sawmill industry, commercial motor parks, } \\
\text { Retailing shops. }\end{array}$ \\
\hline 2 & Surulere/Agbooba & 4-legged & $\begin{array}{l}\text { Markets, Commercial centres, Institutional, Residential estate, } \\
\text { Retailing shops. }\end{array}$ \\
\hline 3 & $\begin{array}{l}\text { Oloje/Mount Carmel } \\
\text { College }\end{array}$ & 3-legged & $\begin{array}{l}\text { Market, Commercial centres, motor park, Institutional, } \\
\text { Residential estate, Retailing shops. }\end{array}$ \\
\hline 4 & Taiwo/Ita Amodu & 4-legged & Commercial centres, Retailing shops, Institutional. \\
\hline 5 & Murtala/Amilegbe & 4-legged & $\begin{array}{l}\text { Motor park, Institutional, Offices, Market, Commercial } \\
\text { centres, Retailing shops, Government Residential Area. }\end{array}$ \\
\hline 6 & Tanke/Tipper Garage & 4-legged & $\begin{array}{l}\text { Retailing shops, Institutional, Commercial motor parks, } \\
\text { Government Residential Area. }\end{array}$ \\
\hline 7 & $\begin{array}{l}\text { Gaa-Akanbi/Offa } \\
\text { Garage }\end{array}$ & $\begin{array}{l}\text { Institutional, Retailing shops, Private and public commercial } \\
\text { motor parks, Industrial. }\end{array}$ \\
\hline
\end{tabular}

The table shows that three of the intersections constituting $42.9 \%$ are 3 -legged. These are Sawmill/Airport; Oloje/Mt. Carmel and Gaa Akanbi/Offa Garage. The 4-legged intersections which constitute $57.1 \%$ are Surulere/Agbooba, Taiwo/Ita Amodu, Murtala/Amilegbe and Tanke/Tipper Garage. In terms of land use characteristics of the studied junctions, majority of them are located where institutional, commercial, markets, retailing shops, motor parks predominate. The intersecting arms also connect residential estates, public and private institutions and other major activity-centres in the city.

\subsection{Pattern of Traffic Flow and Traffic Delay}

The average traffic volumes in vehicles per hour (vph) and traffic delay in minutes at the studied intersections during the peak period are shown on TABLE 2 and Fig. 2. The analysis reveals that Murtala Mohammed/Amilegbe junction recorded the highest volume of traffic and delay among the studied roads. These are $5588 \mathrm{vph}(17.4 \%)$ and 119 minutes $(18.9 \%)$ of total traffic volume and delay respectively. The high volume of traffic flow and delay at this junction exemplifies the importance of the roads converging at this junction and the land use activities they serve. Murtala Mohammed Road services Post Office and the commercial activities along it. The northern arm of the road services Maraba Motor Park, Kwara State Polytechnic main campus, Ilorin Government Secondary School and Federal Secretariat while Amilegbe road services Ipata Market, University of Ilorin Teaching Hospital Maternity Centre and many retailing shops. These activities account for the high volume of traffic at the junction.

Taiwo/Ita Amodu junction is another road experiencing high volume of traffic and delay. It ranks second with 5,408 vph (16.8\%) and 109 minutes (17.3\%) for traffic volume and delay respectively. Taiwo road is one of the busiest commercial belts in Ilorin with supermarkets, eateries, retailing shops along it. Ita Amodu road also services many commercial activities along it and links with Oja Oba market in the heart of the city. Adamu road directly opposite Ita Amodu road also contributes to the traffic volume at this junction resulting from commercial and institutional land use along it.

Surulere/Agbo-Oba junction ranks third recording 4,980 vph (15.5\%) and 100 minutes (15.8\%) traffic volume and delay respectively. The volume of flow and delay at Surulere/Agbo Oba junction also explains the importance of the roads converging at the junction. These are Abdulaziz Attah road which carries a lot of traffic from Oja-Oba, Baboko Market and the University of Ilorin Teaching Hospital, Agbo Oba road services the heavily populated residential area of Agbo-Oba and Adewole Housing Estate while Surulere road links the junction with Taiwo road with retailing shops along it. 
Tanke/Tipper Garage junction is an emerging commercial centre with University of Ilorin permanent site road, Pipeline road and Tipper garage road radiating from it. The junction ranks fourth recording 4,547 vph $(14.2 \%)$ traffic volumes and 88 minutes $(14.0 \%)$ traffic delay. The University of Ilorin road services University of Ilorin permanent site and an array of secondary and primary schools, residential and commercial uses along it. Pipeline road services a new Government Reservation Area and links with Ajase-Ipo road to the South which also harbours residential and commercial land uses. Tipper garage road services predominantly residential areas to the north of the junction.

Sawmill/Airport junction ranks fifth for traffic volume recording 3,999 vph (12.5\%) but ranks sixth for traffic delay with a record of 75 minutes (11.9\%). The converging roads at this junction services commercial, institutional and residential land uses. Sawmill garage road links with an important motor garage in the city. This garage caters for vehicles carrying passengers to Lagos, Ibadan, Abeokuta, and Ogbomoso. The road also accommodates commercial activities along it. Airport road is an extension of AbdulAziz Attah road and services the Ilorin international Airport with a lot of commercial activities along it.

Gaa-Akanbi/Offa Garage junction ranks sixth with 3,820 vph (11.9\%) for traffic volume and ranks fifth for traffic delay recording 79 minutes (12. 5\%). This junction is a convergence of predominantly residential and commercial land uses. Gaa-Akanbi road services Gaa-Akanbi residential quarters with some commercial activities along it while Offa road links with Offa garage to the South-east and some residential, commercial and institutional land uses along it.

Oloje/Mt. Carmel junction ranks seventh for both traffic volume and delay, with 3,788 vph (11.8\%) and 60 minutes $(9.6 \%)$ respectively. This junction is located in the western end of the city and services residential and institutional land uses. These include Oloje residential quarters, Ogidi village, Mt. Carmel College, Federal Government College and Oko Olowo quarters.

Overall, the delay times to a large extent are associated with the traffic volumes at the various junctions which ultimately translate to traffic congestion. The distribution of traffic volume and traffic delay at the sampled intersections depicts the nature of the predominant land use activities which the roads converging at the junction serve and their classification within the general road network pattern of the city. Three out of the four arms of Murtala Mohammed/Amilegbe junction are dual carriage ways while two out of the four arms of Taiwo/Ita Amodu junction are dual carriage way. Surulere/Agbo-Oba junction also has two out of its four arms as dual carriage ways while Tanke/Tipper garage junction has three out of its four arms as dual carriage ways. The Sawmill/Airport junction has two out of its three arms as dual carriage ways while Mt. Carmel/Oloje junction and Gaa-Akanbi/Offa garage junction each has two of its three arms as dual carriage ways. Consequently, they all carry significant volume of traffic within the city's road network pattern.

Table 2: Average Volume of Traffic and Delay at the Studied Intersection

\begin{tabular}{|c|c|c|c|c|c|c|}
\hline \multirow[t]{2}{*}{$\mathbf{S} / \mathbf{N}$} & \multirow[t]{2}{*}{ Intersection } & \multirow[t]{2}{*}{ Approach } & \multicolumn{2}{|c|}{$\begin{array}{l}\text { Avg. Peak Hour } \\
\text { Traffic Volume }\end{array}$} & \multicolumn{2}{|c|}{$\begin{array}{l}\text { Avg. Peak Hour Delay Time } \\
\text { (Minutes) }\end{array}$} \\
\hline & & & VPH & \% of Total & Minutes & \% of Total \\
\hline \multirow[t]{4}{*}{1} & \multirow[t]{4}{*}{ Sawmill/Airport } & Col. of Ed. & 1524 & 4.7 & 29 & 4.6 \\
\hline & & Airport & 1544 & 4.8 & 31 & 4.9 \\
\hline & & Sawmill Garage & 931 & 3.0 & 15 & 2.4 \\
\hline & & Total & 3999 & 12.5 & 75 & 11.9 \\
\hline \multirow[t]{5}{*}{2} & \multirow[t]{5}{*}{ Surulere/Agbo-Oba } & Oja-Oba & 1533 & 4.8 & 28 & 4.4 \\
\hline & & General & 1536 & 4.8 & 27 & 4.3 \\
\hline & & Agbo-Oba & 989 & 3.1 & 27 & 4.3 \\
\hline & & Surulere & 922 & 2.9 & 18 & 2.9 \\
\hline & & Total & 4980 & 15.5 & 100 & 15.8 \\
\hline \multirow[t]{4}{*}{3} & \multirow[t]{4}{*}{ Oloje/Mt. Carmel } & Oloje & 1427 & 4.4 & 23 & 3.7 \\
\hline & & Oja-Oba & 1423 & 4.4 & 22 & 3.5 \\
\hline & & Adeta & 938 & 2.9 & 15 & 2.4 \\
\hline & & Total & 3788 & 11.8 & 60 & 9.6 \\
\hline \multirow[t]{5}{*}{4} & \multirow[t]{5}{*}{ Taiwo/Ita Amodu } & Taiwo Oke & 1625 & 5.1 & 33 & 5.2 \\
\hline & & Taiwo Isale & 1680 & 5.2 & 30 & 4.8 \\
\hline & & Ita amodu & 1086 & 3.3 & 24 & 3.8 \\
\hline & & Adamu & 1017 & 3.2 & 22 & 3.5 \\
\hline & & Total & 5408 & 16.8 & 109 & 17.3 \\
\hline \multirow[t]{4}{*}{5} & \multirow[t]{4}{*}{ Murtala/Amilegbe } & Sango & 1490 & 4.6 & 33 & 5.2 \\
\hline & & Post Oficce & 1502 & 4.7 & 30 & 4.8 \\
\hline & & Amilegbe & 1512 & 4.7 & 34 & 5.4 \\
\hline & & Sabo Oke & 1084 & 3.4 & 22 & 3.5 \\
\hline
\end{tabular}


Assessment Of Traffic Delay Problems And Characteristics At Urban Road Intersections: A Case Study

\begin{tabular}{|l|l|l|l|l|l|l|}
\hline & & Total & $\mathbf{5 5 8 8}$ & $\mathbf{1 7 . 4}$ & $\mathbf{1 1 9}$ & $\mathbf{1 8 . 9}$ \\
\hline 6 & \multirow{4}{*}{ Tanke/Tipper Garage } & University & 1516 & 4.7 & 29 & 4.6 \\
\cline { 3 - 6 } & & Tanke & 1450 & 4.5 & 26 & 4.2 \\
\cline { 3 - 6 } & Pipeline & 980 & 3.1 & 21 & 3.3 \\
\cline { 3 - 6 } & & Tipper Garage & 601 & 1.9 & 12 & 1.9 \\
\cline { 3 - 6 } & & Total & $\mathbf{4 5 4 7}$ & $\mathbf{1 4 . 2}$ & $\mathbf{8 8}$ & $\mathbf{1 4 . 0}$ \\
\hline 7 & \multirow{3}{*}{\begin{tabular}{l} 
Gaa-Akanbi/Offa \\
\cline { 3 - 6 }
\end{tabular}} & A-division & 1470 & 4.6 & 28 & 4.4 \\
\cline { 3 - 6 } & Offa Garage & 1443 & 4.5 & 31 & 4.9 \\
\cline { 3 - 6 } & Gaa-Akanbi & 907 & 2.8 & 20 & 3.2 \\
\cline { 3 - 6 } & Total & $\mathbf{3 8 2 0}$ & $\mathbf{1 1 . 9}$ & $\mathbf{7 9}$ & $\mathbf{1 2 . 5}$ \\
\hline \multicolumn{2}{|l|}{ Grand Total for all Intersections } & $\mathbf{3 2 1 3 0}$ & $\mathbf{1 0 0}$ & $\mathbf{6 3 0}$ & $\mathbf{1 0 0}$ \\
\hline
\end{tabular}

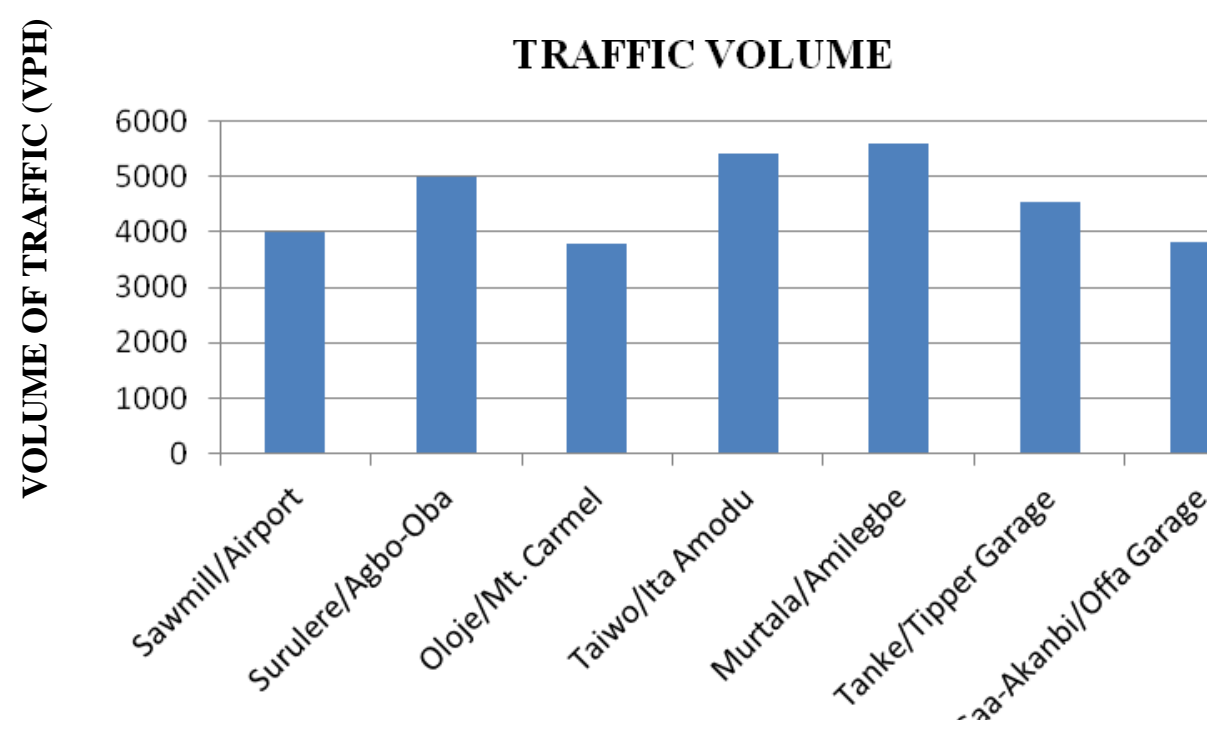

INTERSECTIONS

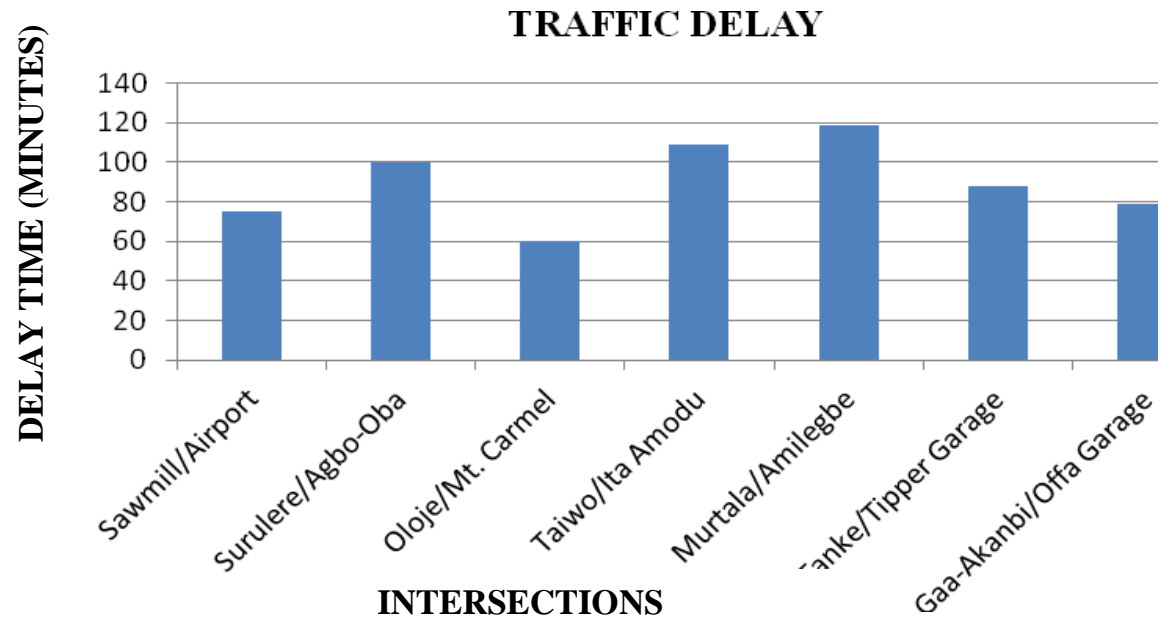

Figure 2: Average Peak Hour Traffic Volume and Delay at the Studied Intersections 


\subsection{Patterns of Traffic Composition and Time Spent by Vehicle Types in Delay}

TABLE 3 and Fig. 3 show the average peak-hour traffic composition and time spent by vehicle types in delay at the sampled intersections. Of all the vehicle types recorded at the sampled junctions, motorcycles had the highest numbers of an average of 1372 vehicles (29.9\%). The dominance of motorcycles among the types of vehicles recorded shows the emerging trend in the use of motorcycles for public transportation in the city. This mode is now becoming popular and it has helped a lot in reducing the transportation problem in the city.

Taxis with an average of 1370 vehicles $(29.8 \%)$ ranks second. In meeting the needs of the inhabitants in terms of public transportation taxis are a regular mode to use. Private cars ranked third with 1143 vehicles $(24.9 \%)$. This shows that there are now more private cars on the city's roads due to improved income and better purchasing power of workers. Buses which provide services for the transportation of goods and people came fourth with 386 vehicles $(8.4 \%)$ while delivery vans which are used mainly for transporting goods in the city recorded an average number of 219 vehicles (4.8\%). Trucks, trailers, lorries, tankers and tippers are heavygoods vehicles and had a record of 98 (2.1\%). They provide intra-city and inter-city services for the transportation of goods, materials for housing construction and petroleum products. Other vehicles such as bicycles, wheel barrows, hand-pushed trucks and carts accounted for the least with an average volume of 4 vehicles $(0.1 \%)$.

In addition, traffic delay times are distributed among the vehicle categories and are found to follow similar pattern with traffic composition at the studied intersections. The analysis revealed that taxis accounted for the greatest time spent in delay with an average time of 23 minutes $(25.6 \%)$. This is followed by motorcycles recording 20 minutes (22.4), private cars 19 minutes (20.5\%), buses 11 minutes (12.8\%), delivery vans 8 minutes $(9 \%)$ and trucks/ trailers/tankers 8 minutes $(8.7 \%)$ in descending order. Other vehicles such as bicycles, wheel barrows, hand-pushed trucks and carts accounted for the least with an average delay time of 1 minute (1\%).

Table 3: Traffic Composition and Vehicle Involved in Delay at the Studied Junctions

\begin{tabular}{|c|c|c|c|c|c|c|c|c|c|c|c|c|c|c|c|c|}
\hline \multirow{2}{*}{$\begin{array}{l}\mathbf{S} / \\
\mathbf{N}\end{array}$} & \multirow[t]{2}{*}{ Intersection } & \multirow[t]{2}{*}{ Approach } & \multicolumn{7}{|c|}{ Traffic Volume Composition (VPH) } & \multicolumn{7}{|c|}{ Vehicle Involved in Traffic Delay (minutes) } \\
\hline & & & $\mathbf{A}$ & $\mathbf{B}$ & $\mathbf{C}$ & D & $\mathbf{E}$ & $\mathbf{F}$ & $\mathbf{G}$ & $\mathbf{A}$ & $\mathbf{B}$ & $\mathbf{C}$ & D & $\mathbf{E}$ & $\mathbf{F}$ & $\mathbf{G}$ \\
\hline \multirow[t]{4}{*}{1} & \multirow{4}{*}{$\begin{array}{l}\text { Sawmill/Airpo } \\
\mathrm{rt}\end{array}$} & Col. of Ed. & 443 & 387 & 434 & 143 & 78 & 36 & 1 & 7 & 7 & 8 & 4 & 3 & 2 & - \\
\hline & & Airport & 456 & 385 & 461 & 115 & 81 & 45 & 1 & 7 & 6 & 8 & 4 & 2 & 2 & - \\
\hline & & $\begin{array}{l}\text { Sawmill } \\
\text { Garage }\end{array}$ & 297 & 222 & 292 & 61 & 40 & 19 & 2 & 5 & 3 & 4 & 1 & 1 & 1 & - \\
\hline & & Total & $\begin{array}{l}119 \\
6\end{array}$ & 994 & $\begin{array}{l}118 \\
7\end{array}$ & 319 & 199 & 100 & 4 & 19 & 16 & 20 & 9 & 6 & 5 & - \\
\hline \multirow[t]{5}{*}{2} & \multirow{5}{*}{$\begin{array}{l}\text { Surulere/Agbo } \\
\text {-Oba }\end{array}$} & Oja-Oba & 445 & 394 & 440 & 134 & 83 & 38 & 2 & 8 & 7 & 9 & 5 & 4 & 3 & - \\
\hline & & General & 440 & 405 & 435 & 138 & 80 & 37 & 1 & 7 & 8 & 6 & 4 & 2 & 4 & - \\
\hline & & Agbo-Oba & 309 & 237 & 299 & 69 & 56 & 18 & 1 & 5 & 2 & 5 & 2 & 3 & 1 & $\begin{array}{l}0 . \\
6\end{array}$ \\
\hline & & Surulere & 298 & 217 & 289 & 59 & 43 & 15 & 1 & 4 & 2 & 5 & 1 & 1 & 1 & $\begin{array}{l}0 . \\
4\end{array}$ \\
\hline & & Total & $\begin{array}{l}149 \\
2\end{array}$ & $\begin{array}{l}125 \\
3\end{array}$ & $\begin{array}{l}146 \\
3\end{array}$ & 400 & 262 & 108 & 5 & 24 & 19 & 25 & 12 & 10 & 9 & 1 \\
\hline \multirow[t]{4}{*}{3} & \multirow{4}{*}{$\begin{array}{l}\text { Oloje/Mt. } \\
\text { Carmel }\end{array}$} & Oloje & 436 & 372 & 431 & 93 & 61 & 33 & 1 & 5 & 5 & 5 & 3 & 2 & 3 & - \\
\hline & & Oja-Oba & 432 & 396 & 427 & 70 & 64 & 33 & 2 & 6 & 4 & 7 & 3 & 2 & 2 & - \\
\hline & & Adeta & 308 & 239 & 301 & 43 & 30 & 15 & 1 & 3 & 2 & 4 & 1 & 2 & 1 & - \\
\hline & & Total & $\begin{array}{l}117 \\
6\end{array}$ & $\begin{array}{l}100 \\
7\end{array}$ & $\begin{array}{l}115 \\
9\end{array}$ & 206 & 155 & 81 & 4 & 14 & 11 & 16 & 7 & 6 & 6 & - \\
\hline \multirow[t]{5}{*}{4} & \multirow{5}{*}{$\begin{array}{l}\text { Taiwo/Ita } \\
\text { Amodu }\end{array}$} & Taiwo Oke & 476 & 383 & 485 & 154 & 88 & 38 & 1 & 7 & 9 & 8 & 5 & 4 & 4 & - \\
\hline & & Taiwo Isale & 495 & 402 & 495 & 152 & 95 & 40 & 1 & 9 & 8 & 10 & 5 & 4 & 3 & - \\
\hline & & Ita amodu & 332 & 259 & 340 & 92 & 40 & 17 & 1 & 4 & 3 & 5 & 2 & 2 & 2 & $\begin{array}{l}0 . \\
5\end{array}$ \\
\hline & & Adamu & 326 & 255 & 324 & 65 & 37 & 16 & 1 & 3 & 2 & 4 & 2 & 2 & 1 & $\begin{array}{l}0 . \\
5\end{array}$ \\
\hline & & Total & $\begin{array}{l}162 \\
9\end{array}$ & $\begin{array}{l}129 \\
9\end{array}$ & $\begin{array}{l}164 \\
4\end{array}$ & 463 & 260 & 111 & 4 & 23 & 22 & 27 & 14 & 12 & 10 & 1 \\
\hline \multirow[t]{5}{*}{5} & \multirow{5}{*}{$\begin{array}{l}\text { Murtala/Amile } \\
\text { gbe }\end{array}$} & Sango & 421 & 358 & 458 & 167 & 66 & 20 & 1 & 6 & 7 & 6 & 5 & 5 & 5 & - \\
\hline & & Post Oficce & 421 & 376 & 444 & 148 & 88 & 24 & 1 & 7 & 6 & 7 & 4 & 4 & 3 & - \\
\hline & & Amilegbe & 453 & 353 & 437 & 153 & 91 & 24 & 1 & 8 & 9 & 11 & 6 & 2 & 2 & - \\
\hline & & Sabo Oke & 342 & 253 & 344 & 85 & 43 & 15 & 1 & 4 & 2 & 5 & 1 & 2 & 1 & 1 \\
\hline & & Total & $\begin{array}{l}163 \\
7\end{array}$ & $\begin{array}{l}134 \\
0\end{array}$ & $\begin{array}{l}168 \\
3\end{array}$ & 553 & 288 & 83 & 4 & 25 & 24 & 29 & 16 & 13 & 11 & 1 \\
\hline \multirow[t]{5}{*}{6} & \multirow{5}{*}{$\begin{array}{l}\text { Tanke Tipper } \\
\text { Garage }\end{array}$} & University & 419 & 418 & 434 & 141 & 63 & 34 & 1 & 6 & 8 & 9 & 6 & 1 & 1 & - \\
\hline & & Tanke & 403 & 402 & 412 & 138 & 59 & 35 & 1 & 7 & 7 & 4 & 6 & 1 & 2 & - \\
\hline & & Pipeline & 320 & 234 & 304 & 69 & 36 & 17 & 1 & 5 & 4 & 5 & 1 & 1 & 2 & - \\
\hline & & $\begin{array}{l}\text { Tipper } \\
\text { Garage }\end{array}$ & 194 & 148 & 186 & 30 & 23 & 19 & 2 & 2 & 1 & 1 & - & 1 & 4 & - \\
\hline & & Total & $\begin{array}{l}133 \\
6\end{array}$ & $\begin{array}{l}120 \\
2\end{array}$ & $\begin{array}{l}133 \\
6\end{array}$ & 378 & 181 & 105 & 5 & 20 & 20 & 22 & 13 & 4 & 9 & - \\
\hline \multirow[t]{4}{*}{7} & \multirow{4}{*}{$\begin{array}{l}\text { Gaa- } \\
\text { Akanbi/Offa } \\
\text { Garage }\end{array}$} & A-division & 430 & 363 & 421 & 150 & 69 & 41 & 1 & 6 & 8 & 10 & 3 & 2 & 2 & - \\
\hline & & Offa Garage & 419 & 327 & 416 & 163 & 76 & 43 & 1 & 7 & 6 & 8 & 6 & 2 & 2 & - \\
\hline & & Gaa-Akanbi & 287 & 216 & 281 & 67 & 42 & 13 & 1 & 4 & 4 & 5 & 1 & 2 & 1 & - \\
\hline & & Total & $\begin{array}{l}113 \\
6\end{array}$ & 906 & $\begin{array}{l}111 \\
8\end{array}$ & 380 & 187 & 97 & 3 & 17 & 18 & 23 & 10 & 6 & 5 & - \\
\hline \multicolumn{3}{|c|}{ T Total for all Intersections } & 960 & 800 & 959 & 269 & 153 & 685 & 29 & 142 & 130 & 162 & 81 & 57 & 55 & 6 \\
\hline
\end{tabular}


Assessment Of Traffic Delay Problems And Characteristics At Urban Road Intersections: A Case Study

\begin{tabular}{ll|l|l|l|l|l|l|l|l|l|l|l|l|l|l|}
\hline & $\mathbf{2}$ & $\mathbf{1}$ & $\mathbf{0}$ & $\mathbf{9}$ & $\mathbf{2}$ & & & & & & & & & \\
\hline Average & $\mathbf{1 3 7}$ & $\mathbf{1 1 4}$ & $\mathbf{1 3 7}$ & $\mathbf{3 8 6}$ & $\mathbf{2 1 9}$ & $\mathbf{9 8}$ & $\mathbf{4}$ & $\mathbf{2 0}$ & $\mathbf{1 9}$ & $\mathbf{2 3}$ & $\mathbf{1 1}$ & $\mathbf{8}$ & $\mathbf{8}$ & $\mathbf{1}$ \\
\hline Percentage & $\mathbf{2}$ & $\mathbf{2 9 . 9}$ & $\mathbf{2 4 . 9}$ & $\mathbf{2 9 . 8}$ & $\mathbf{8 . 4}$ & $\mathbf{4 . 8}$ & $\mathbf{2 . 1}$ & $\mathbf{0 . 1}$ & $\mathbf{2 2 . 4}$ & $\mathbf{2 0 . 5}$ & $\mathbf{2 5 . 6}$ & $\mathbf{1 2 . 8}$ & $\mathbf{9 . 0}$ & $\mathbf{8 .}$ & $\mathbf{1}$ \\
\hline
\end{tabular}

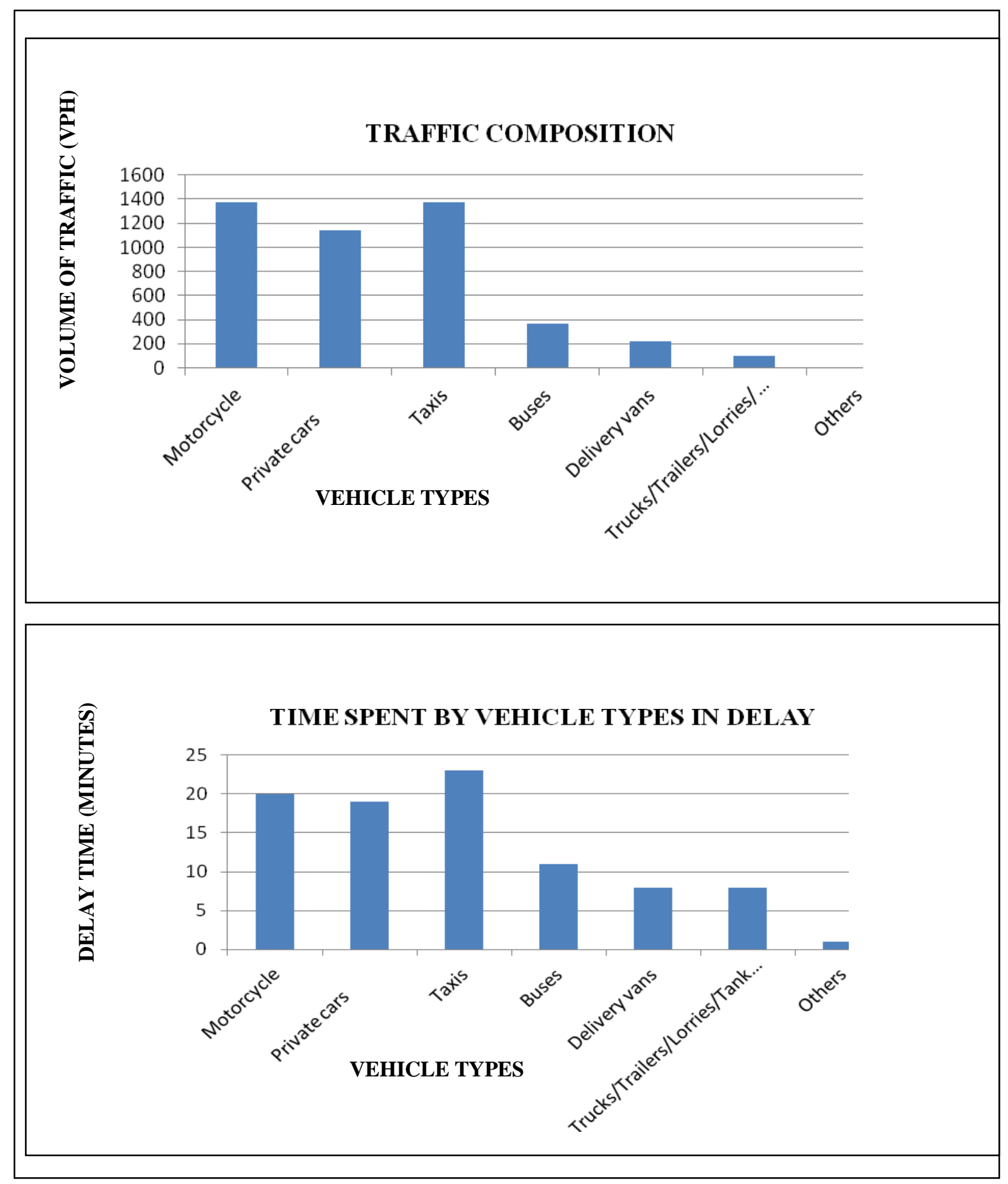

Figure 3: Traffic Composition and Vehicle Involved in Delay at the Studied Junctions 


\subsection{Traffic Delay Causes and Time Taken}

The patterns of time taken by delay causes in average daily peak-hour traffic delay are shown on TABLE 4 and Fig. 4. The analysis shows that of all the delay causes, traffic controller/wardens ranks first with an average 42 minutes and constituting $46.8 \%$ of the total delay time. The problem of traffic wardens can be attributed to the absence of modern traffic management techniques at the road intersections. Since human labour for traffic control is susceptible to failure due to fatigue and exhaustion, the traffic wardens are therefore not efficient or present to control the traffic when they are exhausted or during bad weather (like rainfall and in some cases, scorching sunshine).

Parking problems with an average of 21 minutes $(23.3 \%)$ of total delay time came second. The parking problems experienced include on-street parking, double parking, and parking to load and off -load which reduce the road space thereby impeding the free movement of vehicles. The parking problems found can be attributed to narrowness of the intersecting roads which do not give room for side-kerbed parking. In addition, there is no provision for off-street parking in the city and as such vehicles have no alternative than to use the roads as parking space. This therefore gives room for indiscriminate on-street parking and parking to load and off-load.

Turning and maneuvering problems rank third taking an average of 8 minutes and constitute 9.5\%. This can be attributed to the narrowness and the non-channelization of most of the intersecting roads. Vehicle breakdown and accidents take an average of 6 minutes and 5 minutes and accounting for $6.8 \%$ and $5.4 \%$ respectively of total delay time. Also road-side hawking and retailing account for an average of 4 minutes delay time constituting $4.0 \%$ of total delay while pedestrian crossing accounts for only 2 minutes delay time which is $2.5 \%$ of total delay. Other causes of delay identified include conflicts, construction works and rainfall which also account for an average of 2 minutes constituting $1.7 \%$ of total delay time.

Table 4: Delay Causes at Studied Intersections

\begin{tabular}{|c|c|c|c|c|c|c|c|c|c|c|}
\hline $\mathbf{S} / \mathbf{N}$ & Intersection & Approach & \multicolumn{8}{|c|}{ Time wasted by Delay Causes (minutes) } \\
\hline \multirow[t]{3}{*}{1} & \multirow[t]{3}{*}{ Sawmill/Airport } & Col. of Ed. & 13 & 2 & 9 & 0.5 & 3 & 1 & 2 & 0.7 \\
\hline & & Airport & 16 & 1 & 6 & 0.2 & 1 & 2 & 1 & 0.3 \\
\hline & & Total & 37 & 4 & 19 & 1 & 5 & 4 & 4 & 1 \\
\hline \multirow[t]{3}{*}{2} & \multirow{3}{*}{$\begin{array}{l}\text { Surulere/Agbo- } \\
\text { Oba }\end{array}$} & Oja-Oba & 16 & 1 & 6 & 1 & - & 1 & 2 & 1 \\
\hline & & General & 13 & 1 & 4 & 0.4 & - & 1 & 1 & 1 \\
\hline & & Total & 45 & 7 & 22 & 2 & 4 & 9 & 9 & 2 \\
\hline \multirow[t]{4}{*}{3} & \multirow[t]{4}{*}{ Oloje/Mt. Carmel } & Oloje & 10 & 1 & 6 & 1 & 0.3 & 1 & 3 & - \\
\hline & & Oja-Oba & 12 & - & 5 & 0.4 & - & - & 2 & 0.4 \\
\hline & & Adeta & 7 & 1 & 4 & 0.6 & 0.7 & 1 & 3 & 0.6 \\
\hline & & Total & 29 & 2 & 15 & 2 & 1 & 2 & 8 & 1 \\
\hline 4 & Taiwo/Ita Amodu & Taiwo Oke & 14 & 2 & 7 & 1 & 2 & 3 & 2 & 0.6 \\
\hline \multirow[t]{5}{*}{5} & \multirow{5}{*}{$\begin{array}{l}\text { Murtala/Amilegb } \\
\mathrm{e}\end{array}$} & Sango & 15 & 3 & 6 & 1 & 1 & 2 & 3 & - \\
\hline & & Post Oficce & 14 & 1 & 7 & 1 & 1 & 2 & 2 & 1 \\
\hline & & Amilegbe & 16 & 2 & 8 & - & - & 3 & 2 & 1 \\
\hline & & Sabo Oke & 10 & 2 & 7 & 1 & 1 & 2 & 4 & - \\
\hline & & Total & 55 & 8 & 28 & 3 & 3 & 9 & 11 & 2 \\
\hline \multirow[t]{5}{*}{6} & \multirow{5}{*}{$\begin{array}{ll}\text { Tanke } & \text { Tipper } \\
\text { Garage } & \end{array}$} & University & 15 & 1 & 8 & - & 1 & 2 & 2 & 1 \\
\hline & & Tanke & 12 & 1 & 6 & 1.3 & 2 & 1 & 3 & - \\
\hline & & Pipeline & 8 & 1 & 4 & - & 2 & 1 & 3 & - \\
\hline & & Tipper Garage & 5 & - & 2 & 0.7 & - & - & 2 & - \\
\hline & & Total & 40 & 3 & 20 & 2 & 5 & 5 & 11 & 2 \\
\hline \multirow[t]{3}{*}{7} & \multirow{3}{*}{$\begin{array}{l}\text { Gaa-Akanbi/Offa } \\
\text { Garage }\end{array}$} & A-division & 15 & 2 & 6 & - & 0.5 & 1 & 3 & 2 \\
\hline & & Offa Garage & 17 & 20 & 5 & - & 0.5 & 2 & 2 & - \\
\hline & & Gaa-Akanbi & 10 & 4 & 16 & 1 & 1 & 6 & 7 & 2 \\
\hline
\end{tabular}

A = Traffic Controller/Wardens

$\mathrm{B}=$ Accident

$\mathrm{C}=$ parking problems

$\mathrm{D}=$ Pedestrian Crossing
$\mathrm{E}=$ Road-side hawking \& Retailing

$\mathrm{F}=$ Vehicle Breakdown

$\mathrm{G}=$ Vehicle turning \& Maneuvering Problems

$\mathrm{H}=$ Others 


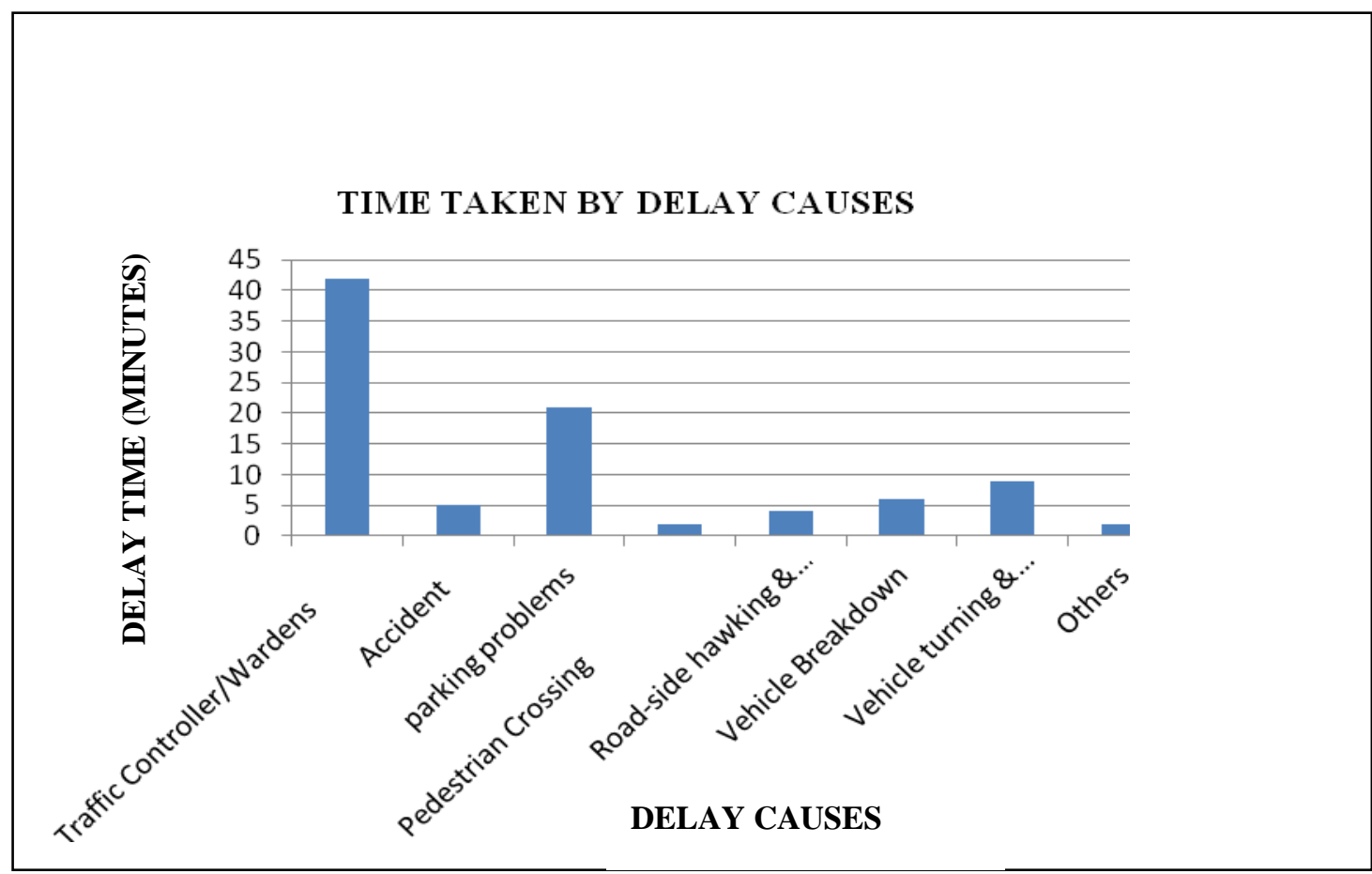

\section{Figure 4: Time wasted by Delay Causes}

\section{Recommendations and Implications for Urban Transportation Planning}

The study of traffic delay problems at sampled intersections in Ilorin revealed that there are significant spatial variations in traffic flows and delay times at the studied intersections during peak period. These variations can be attributed to the differences in land use characteristics at the intersections and the areas served by the converging roads. Moreover, the proportion of traffic delay times was found to be spatially related to the volume of vehicles at the studied intersections.

This study has implications for urban transportation planning. Firstly, the designs of the road intersections in the study area should be reviewed such that the approaches are broad for a distance of about 200 metres to avoid obstruction of side turning vehicles by the straight moving ones. All the approaches to the intersections should also be channelized to separate traffic streams. Also, road-side hawking and trading and all forms of commercial activities should be strictly restricted up to a distance of 200 metres from the intersections. Town planning control mechanism should be used to control developments around the intersections.

The public transportation system in the city should be improved by introducing high-occupancy vehicles to work alongside with taxis and motorcycles for the conveyance of people in the study area. This will reduce the number of vehicles on the road. Besides, there is the need to signalize the intersections by installing traffic lights and signals to serve as substitute for the ineffective human labour of traffic management.

In addition, there is the need for provision of off-street parking spaces in Ilorin and along the intersecting roads. Also on-street parking of whatever types should be strictly restricted up to a distance of 200 metres away from the intersections. This can be done by installing NO PARKING and NO WAITING signs at the intersections to discourage arbitrary parking. Many of the problems identified at the studied junctions are common to other road intersections in the city. The recommendations made are therefore useful for solving traffic congestion problems at road intersections generally in the city.

\section{Conclusion}

The study examined traffic delay problems at road intersections in Ilorin and has offered useful suggestions for improving traffic flow at the junctions. Though the traffic flow problem in Ilorin has not yet assumed the deplorable stage/dimension of those of Lagos, Ibadan, Port-Harcourt and other bigger urban centres in Nigeria, signs of potential bottlenecks are already emerging as demonstrated by the present trends at the studied intersections. There is therefore the need to evolve more effective traffic management method for the city. As population increases and people become more affluent, traffic delay problems becomes worse. With the high rate of growth of Ilorin, traffic problem should not be left until it deteriorates to the level of larger urban 
centres in Nigeria. It is on this note that this study has suggested immediate solutions to traffic delay problems at road intersections in Ilorin and many other cities in Nigeria.

\section{References}

[1] Weiping, H., and Chi, W. (2010): Urban Road Network Accessibility Evaluation Method Based on GIS Spatial Analysis Techniques. The International Archives of the Photogrammetry, Remote Sensing and Spatial Information Sciences, Vol. 38 , Part II.

[2] Aderamo, A. J. (2003): A Graph Theoretical Analysis of Intra-Urban Road Network in Ilorin, Nigeria. Research for Development. $17(1 \& 2)$ and $18(1 \& 2)$.

[3] Adedimila, S. A. (1981): Towards Improving Traffic Flow in Lagos. In Onokomaiya and Ekanem (Ed), Transportation in Nigeria National Development. NISER, Ibadan.

[4] Tillotson, H. T. (1981): The Concept of Delay. Transport, 20 (4).

[5] Mchsane, W. R, Roess, P. R, Prassas, E. D. (1998): Traffic Engineering, Second Edition New Jersey: Prentice Hall.

[6] Ogden, K. W. (1991): “Truck movement and access in urban areas". Journal of Transportation Engineering, 117 (1).

[7] Ogunsanya, A. A. (1983): Contribution of Freight Vehicles to Urban Traffic Delays: The Case of Lagos, Nigeria. The Nigerian Geographical Journal, 26 (1\&2).

[8] Ogunsanya, A. A. (1984): Traffic Congestion in an Urban Centre: The Case of Ilorin, Nigeria. The Nigerian Geographical Journal, $27(1 \& 2)$.

[9] O'Flaherty, C. A (1974): Highway and Traffic, Second Edition. London: Edward Arnold Publisher Ltd

[10] Smith, M. J. (1982): Junction Interactions and Monotonicity in Traffic Assignment. Transport Research, 16B (1).

[11] Oyebanji, J. (1983): Kwara State. In Udo, R. K., and Mamman, A. D. (Ed), Nigeria Circuit in the Tropics: State Survey, Vol. 2. Lagos: Gabumo Publishing Co. Ltd.

[12] Kwara State of Nigeria (1997): Kwara State Diary. Ilorin: Government Press.

[13] Aderamo A. J. (2004): transport Factor in the Structure and Growth of a Traditional Settlement-Ilorin, Nigeria. Geo-Studies forum, Vol 2 (1).

[14] Salter, R. J. (1974): Highway Traffic Analysis and Design, London: Macmillan. 